$\mathrm{Ca}^{++}$多量に存在すると過大な值き與えるが, $\mathrm{P} 100 \%$ に對し, $\mathrm{Ca}^{++} 0.1 \mathrm{~g}$ 位 $(\mathrm{P}: \mathrm{Ca}=1: 1000)$ までは妨害

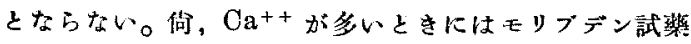
を添加したときに硫酸カルンウムの沈澱を生ずるが，醋 酸ナトリウム處理啳滤别し，滤液を50cckして比色す ればよい。滤渦に依る誤差はない。

$\mathrm{Mg}^{++} \mathrm{P} 100 \gamma$ K對し, $0.2 \mathrm{~g}$ の $\mathrm{Mg}^{++}(\mathrm{P}: \mathrm{Mg}=$ 1:2000) の共存江何等の影響をむ與えない。

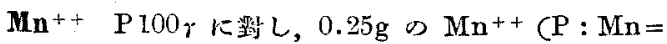
1：2500) の共存は妨害にならない。

$\mathrm{Fe}^{++} \mathrm{P} 100 r$ r對し, $\mathrm{Fe}^{++} 0.1 \mathrm{~g}(\mathrm{P}: \mathrm{Fe}=1: 100$ 0)に於て子妨害は認められない。份, $\mathrm{Fe}^{++}$が多いとき

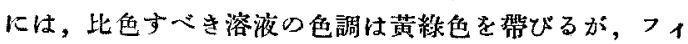
ルター S72 の使用に依り，此の影響を防ざ得る。

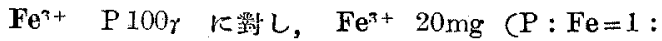
200) に放て名妨害は認めら机ない。多量の $\mathrm{Fe}^{3+}$ の存 在は黃橙色乃至激赫色を與元，著しく妨害する。

$\mathrm{Al}^{3+}$ 多量に存在すると過大な值を與元るが，P100

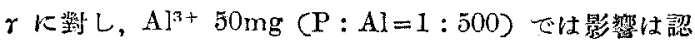
めら机岕以。

Ti $\mathrm{P} 100 \mathrm{r}$ に對 $\mathrm{L}, 1.3 \mathrm{mg} \triangleright \mathrm{Ti}(\mathrm{P}: \mathrm{Ti}=1: 13)$ は 妨害にならない。

Cl-, $\mathrm{SO}_{4}^{--}$㤌多量に存在して 妙管しない。

$\mathrm{NO}_{3}^{-} \mathrm{P} 100 \mathrm{r}$ K齥し, $\mathrm{NO}_{3}^{-}-0.3 \mathrm{~g}\left(\mathrm{P}: \mathrm{NO}_{3}^{-}=1: 30\right.$ 00)に於て子妨害は認められない。多量の $\mathrm{NO}_{3}$ 一の共 存は過小な值を與元る。

$\mathrm{V0}_{3}-\mathrm{P} 100 \mathrm{r}$ 数L, $2.0 \mathrm{mg} \sigma \mathrm{V}(\mathrm{P}: \mathrm{V}=1: 20)$ は妨害にならない。

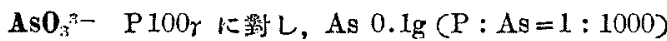
に於てる妙害は認められない。

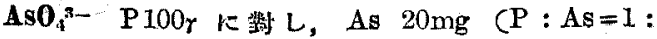
200) に於ても妨甶は憼められない。

$\mathbf{H}_{2} \mathbf{S i O}_{3}$ P100 K覚し Si $20 \mathrm{mg}(\mathrm{P}: \mathrm{Si}=1: 200)$ に於ても妨害は認められない。

$\mathrm{H}_{3} \mathrm{BO}_{3}$ の妨害はない。

\section{結 第}

䗲は䘽鐵元素，親吕元素，親生元素として地球化學的 に甚だ興味の深い元素であるばかりでなく，その分析法 の改良は工業的見地，或任農業的見地等加らも非常に重

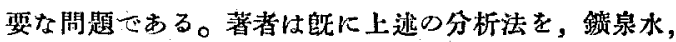
岩石，燐独等の中の橉の定量に適用して極めて良好なる 結果を得たが，それらについては後報する踭定である。

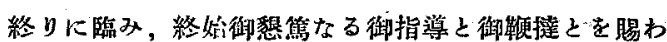
つた木村健二郎先生に証んで感謝の意を表する。

* 以後，簡單のために亞硫酸一重亞硫酸溶液と記す ととにする。

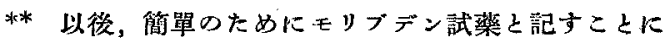
する。

一文献 -

1) 木村, 藤原, 宮住, 昭和 22 年 7 月 (1947 年),

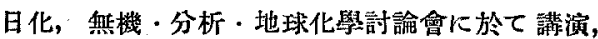

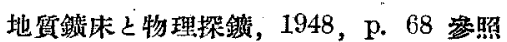

2) L. Losana, Chem. Abstracts, 16, 24,33 (1922); Chem. Zentr., 98 프, 976 (1922).

3) 䖯一男, 日化, 70, 240 (1949).

4) K. O. Scheel, Z. anal. Chem., 105, 256 (1936).

5) Scheel は䢱元蔀として Monomethyl-p-amidophenolsulfatを用いた。

\title{
L-メチオニンのワルデン轉位及び N-メチル-D-メチオニンの生成
}

泉一屋信炎

Fischer 等のアミノ酸のワルデン轉位に關する報告を 綜合すると，まだ赛驗例は少ないのであるが大體次の事

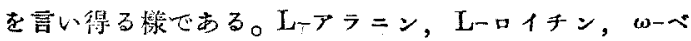
ンゾイル-L-リデン等の如く光學的活性の $\boldsymbol{\alpha}-$ 〉ミ，酸 の $\beta$ 装素が第二級の場合（萿者は假りに（S 型）上呼
ぶ)そのアミノ酸に NOBr の作用で同一型の $a$ ーブ口 ム酸を生じ，それに $\mathrm{NH}_{3}$ を作用させる時ワルデン轉位

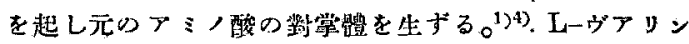
等の如く $\beta$ 炭素が策三級の場合 ( $[$ T型]

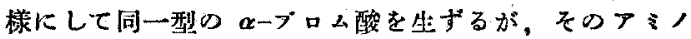


化に際しては轉位は起らないで元の同一型アミ，酸字生

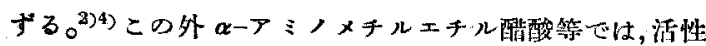
アミノ酸より得られるハロゲン酸が不安定でラセミ化し 易汃つたり或はそのアミ，化の時大部分ラセミ化したア

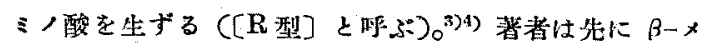
トオキシーLートレオンンは[T型]に屬しワルデン轉位 の起らない整を報告したが,5) N-メチルーD-メチオ=ン を得る目的でメチオニンのワルデン轉位に就いて赛驗し

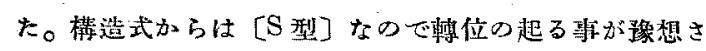
れる。

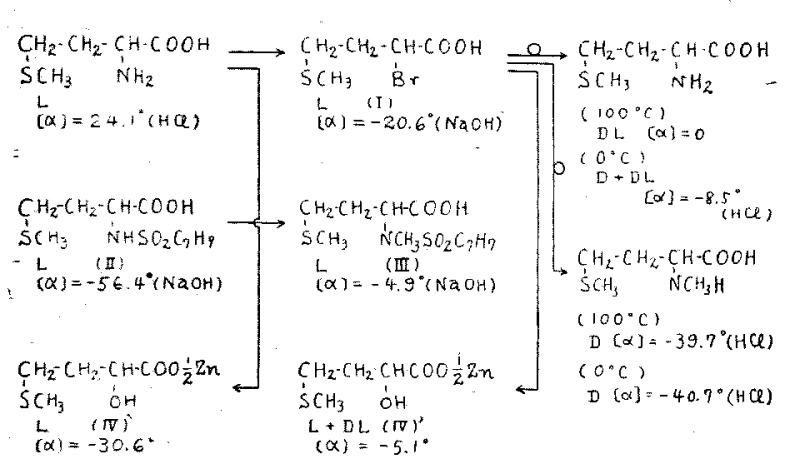

メチオンンに NOBr t作用せしめ圆式の如く（I） 一を得て，之を湯浴中にてアミ，化した啳生成したメチォ ニンは强い甘みがあつたので, 少なくいD型の存在を思 わしめた（し 型は苦い)。然るにその旋光性は全く認め られなかつたので, DLよりなると考えられるが更に $p$ トルエンスルホニル誘導體を作り，， 型の誘導體と 比べて，DLなる事を磪めた。との場合先ず D-メチオ ニンを生成し之が過剩の $\mathrm{NH}_{3}$ によラセミ化されたの ではないかとの疑いを解く俘め，Lーメチォニンを同滕 條件心 $\mathrm{NH}_{3}$ 水中で加謷したが全く綎化がなかつた。同

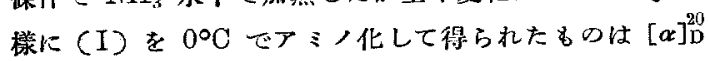
$=-8.5^{\circ}(3 N \mathrm{HCl})$ であり, 之れの $\mathrm{D}$ と $\mathrm{D} \mathrm{L}$ の比は

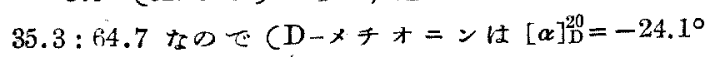
(3N HCl) 飞假定)，相栄にラセミ化を起つているが 明らかにワルデン轎位も認められる。アミノ酸以外では

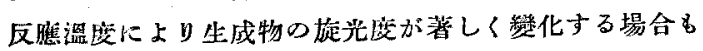
知られているが・アミ，酸心場合溫庭心著しく影揩す る例は殆んど見虽らない。例えば D- $\alpha$-ブロムイソ吉草 酸のアミ：化では $0^{\circ} \mathrm{C} ， 100^{\circ} \mathrm{C}$ 厄同程度に純粹の Dヴァリンを得る゙ (一般に㳦应に係らず多少の(約 10\%)

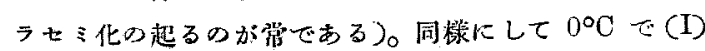

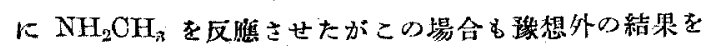
得た。 $\mathrm{NH}_{3}$ と $\mathrm{NH}_{2} \mathrm{CH}_{3}$ の活珄 メーハロゲン酸に對する

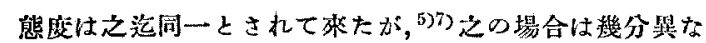

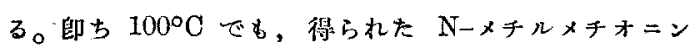
は旋光性を有し，その大いさは $0^{\circ} \mathrm{C} の 反$ 照による場合 と殆んど同一であつた。N-メチルーDLーメチォンンは合 成されているが活，泩體は未知であるので立得られ たものが面ちに D 刑であると即斷は許されない。しか しメチオニンは(S 型)であり，且，N-メチルアミノ酸に ๖ Lutz の法則 ${ }^{9}$ の適用が可能とすれば D 刑と見做す よ゙きである。まだ例は少ないが $\mathrm{L}$ なスチン, ニン1)の N-メチル物は Lutz の法則に從うことが知ら

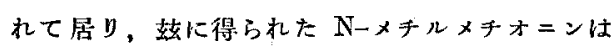
$[\alpha]^{2 D}=-18.6^{\circ}$ (水), $[\alpha]_{\mathrm{D}}^{20}=-40.7^{\circ}(3 N \mathrm{HCl})$ であるからである。この光學的純度は今心所他に 比较すくきるのがないので不明であるが，吻論或 る程度ラ七ミ化しているである5。圆式の(II), (ili) を經る方法でN-メチルメチオニンが得られ るならし 型である5が，常法による（III）の墢 煙監酸の加水分解は成功しなかつた。Lーチスチン

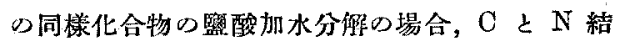
合が切れて求むる $\mathrm{N}$ メチル物の得られないと云 う報告11と類似であるか知れない。 L一メチオ ニンに $\mathrm{HNO}_{2}$ の作用で(N) を生成し,之が L 型なる 事交赤染部氏は報告している。 ${ }^{12}$ ( I ) に $\mathrm{Ag}_{2} \mathrm{O}$ の作用 で同構造の (V) 七ミ化しているが，ワルデン轉位は起つていない。以上 Lーメチオニンは典型的な (S 型) 蓝造ですり作ら, 多分 に( $\mathrm{R}$ 型) 心性質有する點に特徽がある。

\section{實 驗 の 部}

(I) L-メチオニン 蛋白質の加水分䏝により得た。 ので, 滤䌙クロマトグラフにより他に Ninhydrin 斑點 を認めない程度迄 $\left.\mathrm{HgCl}_{2}{ }^{13}\right)$ により精製した。分解點 $275 \sim 278^{\circ} ;[\alpha]_{\mathrm{D}}^{10}=23.9^{\circ}\left(\alpha 1.04^{\circ}\right.$, c. $\left.4.85 \%, 3 N \mathrm{HCl}\right)$ $[\alpha]_{\mathrm{D}}^{20}=24.1^{\circ}\left(\alpha 1.05^{\circ}\right.$, c. $\left.4.35 \%, 3 N \mathrm{HCl}\right)$, 交献 $\left.{ }^{14}\right)$ は $[\boldsymbol{\alpha}]]_{\mathrm{D}}^{\circ}=23.4^{\circ}(\mathrm{c} .5 .0 \%, 3 N \mathrm{HCl})$ 。分析值 $\mathrm{N} 9.52$. $\%, \mathrm{C}_{5} \mathrm{H}_{11} \mathrm{O}_{2} \mathrm{NS}$ 㩐算值 $\mathrm{N} 9.39 \%$ 。

(2) $p$-トルエンスルホニルーL-メチオニン (II) メチオ=ン $0.746 \mathrm{~g}, p$ トルメンスルホニルタロライ F 1.33g, エーテル 4cc, $2 N \mathrm{NaOH}$ 全量 $7.5 \mathrm{cc}$ を常

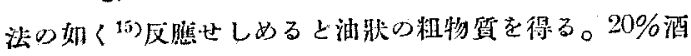

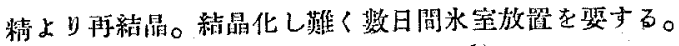

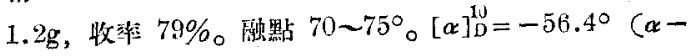
$1.83^{\circ}$, c. $3.24 \%, 1 N \mathrm{NaOH} ;$ この意味は試料 $30.14 \mathrm{mg}$ に溶䍀 $1 N$ NaOH を加天た全最は $978.9 \mathrm{mg}$ ，它心比重 
$d_{4}^{10}=1.053$, 旋光度は $-1.83^{\circ}$, c. $=30.14 \times 1.053 \times 100$

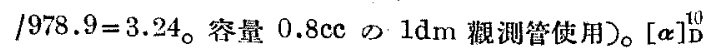
$=15.6^{\circ}\left(\alpha 0.85^{\circ}\right.$, c. $5.44 \%$, 製水酒精)。分析值 $\mathrm{N}$ $4.93 \%, \mathrm{C}_{12} \mathrm{H}_{17} \mathrm{O}_{4} \mathrm{NS}_{2} \mathrm{~N} .4 .62 \%$ 。

(3) N ( $p$-トルエンスルホニル) メチルLーメチオニ ン (III) (II) 融點 $70 \sim 75^{\circ} \odot 0.303 \mathrm{~g}, \mathrm{CH}_{3} \mathrm{I} 0.125$ cc， $2 \mathrm{~N} \mathrm{NaOH} 3 \mathrm{cc}$ を封管中 $70^{\circ} \mathrm{C}$ で應也しめると 速中かに $\mathrm{CH}_{3} \mathrm{I}$ が消失する。20 分間振暨反鹪せしめた 㷋, 常法の如く處理して油狀物を得る。結晶化しないで $20 \%$ 酒精にも相賞可溶性なので, 数问候斜法で水洗す る。乾燥器中放置で淡褐色の松脂狀儿固まる。0.24g, 收集 $77 \%$ 。 $[\alpha]_{D}^{10}=-4.9^{\circ} \quad\left(\alpha-0.14^{\circ}\right.$, c. $2.86 \%, 1 N$ $\mathrm{NaOH}$ )。分析值 $\mathrm{N} 4.09 \%, \mathrm{C}_{13} \mathrm{H}_{19} \mathrm{O}_{4} \mathrm{NS}_{2}$ 計算値 $\mathrm{N} 4$. $42 \%$ 。

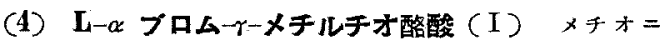
$=4.47 \mathrm{~g}, \mathrm{KBr} 12.48 \mathrm{~g}, 2.5 \mathrm{~N} \mathrm{H}_{2} \mathrm{SO}_{4} \mathrm{e} 2.4 \mathrm{cc}$ の溶液

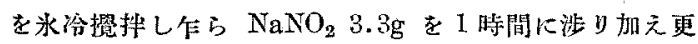

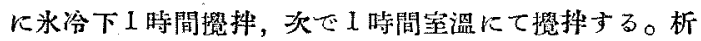

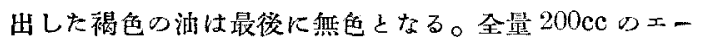
テルを4问に分け抽出，少是の水で洗い，無水 $\mathrm{Na}_{2} \mathrm{SO}_{4}$ で脱水，エーテル溜去 (可及的低温) 寸机壮無色の油を 殘す。 $3.74 \mathrm{~g}$, 收染 $59 \%$ 。 $[\alpha]_{\mathrm{D}}^{20}=-20.6^{\circ}\left(\alpha-0.61^{\circ}\right.$ 。 $\mathrm{c}$. $2.96 \%, I N \mathrm{NaOH}), 乙 \infty 1 N \mathrm{NaOH}$ 溶液を室溫大放 置すると 48 洔間後には旋光度は認められない。油狀物 を L週間乾懆器中放罡与るる, $[\alpha]_{\mathrm{D}}^{20}=-6.0^{\circ}\left(\alpha-0.16^{\circ}\right.$, c. $3.75 \%, I N \mathrm{NaOH}$ )で相常のラセミ化起してい る。この油壯物を分析すると，分析值 $\mathrm{Br} 36.22 \% ， \mathrm{C}_{5}$ $\mathrm{H}_{9} \mathrm{O}_{2} \mathrm{BrS}$ 計算值 $\mathrm{Br} 37.50 \%$ 。

(5) (I) と $\mathrm{NH}_{3}$ の反礁 (a) $100^{\circ} \mathrm{C}$ の場合 (I) の油狀物 $0.8 \mathrm{~g}, 28 \% \mathrm{NH}_{3}$ 水 $8 \mathrm{cc}$ 溫浴中 4 洔間加

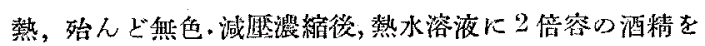
加えると析出する。更に熟水一酒精の再結晶。0.26g,

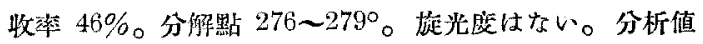
$\mathrm{N} 9.44 \%, \mathrm{C}_{5} \mathrm{H}_{11} \mathrm{O}_{2} \mathrm{NS}$ 計算值 $\mathrm{N} 9.39 \%$ 。

$p$ ートルメンスルホニル誘導體：粗結品を 1 间 $20 \%$ 酒

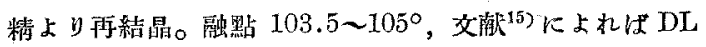
物は 104 105 $01 \mathrm{~N} \mathrm{NaOH}$ 液に旋光性はない。分析 值 $\mathrm{N} 4.88 \%, \mathrm{C}_{12} \mathrm{H}_{17} \mathrm{O}_{4} \mathrm{NS}_{2}$ 計算值 $\mathrm{N} 4.62 \%$ 。 L-x子 オニンと $\mathrm{NH}_{3}$ の蕉沸實驗 : メチォンン $0.1 \mathrm{~g}, \mathrm{NH}_{4} \mathrm{Br}$ $0.065 \mathrm{~g}, 28 \% \mathrm{NH}_{3}$ 水 $1 \mathrm{cc}$ 老封管內溫浴中 4 時間加愁。 问收したメチオニンは $[\alpha]_{\mathrm{D}}^{20}=24.2^{\circ}\left(\alpha 1.10^{\circ}\right.$, c. 4.54 $\%, 3 N \mathrm{HCl}$ 。 (b) $0^{\circ} \mathrm{O}$ の場合 (I) の $0.4 \mathrm{~g}$ 水冷 ᄂ怎万 $\mathrm{NH}_{3}$ 水 $4 \mathrm{cc}$ 加元水中 10 日間放蹎後 (a)

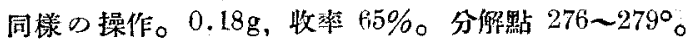

$[\boldsymbol{\alpha}]_{\mathrm{D}}^{20}=-8.5\left(\boldsymbol{\alpha}-0.22^{\circ}\right.$, c. $\left.2.59 \%, 3 N \mathrm{HCl}\right)$ 。分析値 $\mathrm{N} 9.42 \%, \mathrm{C}_{5} \mathrm{H}_{11} \mathrm{O}_{2} \mathrm{NS}$ 計算值 N $9.39 \%$ 。 スルホニル誘導體：結晶し難以。素燒板上乾燥, 融點” $68 \sim 97^{\circ} \circ[\alpha]_{D}^{10}=23.3^{\circ}\left(\alpha 1.16^{\circ}\right.$, c. $4.97 \%, 1 N \mathrm{Na}$ $\mathrm{OH})_{0}$ 分析值 $\mathrm{N} 4.71 \%, \mathrm{O}_{12} \mathrm{H}_{17} \mathrm{O}_{4} \mathrm{NS}_{2}$ 計算侹 $\mathrm{N} 4.62$ \%，(c) 滤紙クロマトグラフによる哈味 Lーメチオ二 ン, (a) のメチオ=ン, (b)のメチオニンの $\mathrm{R}_{\mathrm{f}}$ 價は夫 ↔ $0.545,0.533,0.536$ (溶紧コリヂン十ルチデン十水) であつて，他の共存アミ人酸を检出し得ない。

(b) (I) と $\mathrm{NH}_{2} \mathrm{CH}_{3}$ の反鹰 (a) $100^{\circ} \mathrm{C}$ の場合 : (I) $00.6 \mathrm{~g}, 30 \% \mathrm{NH}_{2} \mathrm{CH}_{3}$ 水 $5 \mathrm{cc}$ 洔間湯浴中

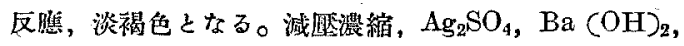
$\mathrm{H}_{2} \mathrm{~S}$ 處理，最後の浱縮物最少量熱水に液かし 4 倍究

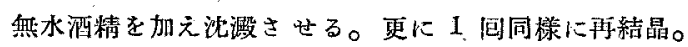
$0.042 \mathrm{~g}$, 收洨 $9 \%$ 。分解點 $236 \sim 238^{\circ}$ (封督)。柱及び 板狀結晶。 $[\alpha]_{\mathrm{D}}^{10}=-17.2^{\circ}\left(\alpha-0.55^{\circ}\right.$, c. $3.20 \%$ 水 $),[\alpha]_{D}^{20}$ $=-17.9^{\circ}(\alpha-0.57$, c. $3.20 \%$, 水 $),[\alpha]_{D}^{10}=-38.1^{\circ}(\alpha$ $-0.74^{\circ}$, c. $\left.1.94 \%, 3 N \mathrm{HCl}\right),[\alpha]_{\mathrm{D}}^{20}=-39.7^{\circ},(\alpha-0$. $77^{\circ}$, c. $1.94 \%, 3 N \mathrm{HCl}$ 。分析值 $\mathrm{N} 8.71 \%, \mathrm{C}_{6} \mathrm{H}_{13} \mathrm{O}_{3}$ $\mathrm{NS}$ 計算值 $\mathrm{N} 8.59 \%$ 。(b) $\mathrm{O}^{\circ} \mathrm{C}$ の場合 : (I) $00.6 \mathrm{~g}$, $30 \% \mathrm{NH}_{2} \mathrm{CH}_{3}$ 水を水中 10 日間放置。(a) 立同栐操作 に上り，0.26 g, 收率 57\%。分解點 238 239 (封管),

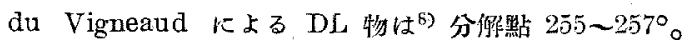
Ninbydrin 反腹は陽性であるが不貽敏で滤縕クロマト

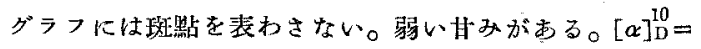
$-17.6^{\circ}\left(\alpha-0.53^{\circ}\right.$, c. $3.01 \%$, 水), $[\alpha]_{D}^{20}=-18.6^{\circ}(\alpha$ $-0.56^{\circ}, \mathrm{c} .3 .01 \%$, 水 $),[\alpha]_{\mathrm{D}}^{0}=-39.2^{\circ}\left(\alpha-0.83^{\circ}\right.$, c. $2.12 \%, 3 N \mathrm{HCl}),[\alpha]_{\mathrm{D}}^{2 j}=-40.7^{\circ}\left(\alpha-0.86^{\circ}\right.$, c. 2.12 $\%, 3 N \mathrm{HCl}$ 。分析檤 $\mathrm{N} 8.66 \%, \mathrm{C}_{6} \mathrm{H}_{13} \mathrm{O}_{2} \mathrm{NS}$ 計算值

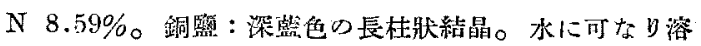
け難い。2200 で褐變, $320^{\circ}$ 浐上り炭化。嘪䠯值 $\mathrm{H}_{2} \mathrm{O}$ $9.14 \%, \mathrm{C}_{12} \mathrm{H}_{24} \mathrm{O}_{4} \mathrm{~N}_{2} \mathrm{~S}_{2} \mathrm{Cu} \cdot 2 \mathrm{H}_{2} \mathrm{O}$ 計算值 $\mathrm{H}_{2} \mathrm{O} \quad 9.30 \%$ 分析值 $\mathrm{N} \quad 7.26 \% \mathrm{Cu} \quad 16.08 \%, \mathrm{C}_{12} \mathrm{H}_{24} \mathrm{O}_{4} \mathrm{~N}_{2} \mathrm{~S}_{2} \mathrm{Cu}$ 計 算值 N 7.22\% Cu 16.37\%。ピタロロナート：分解點 $238 \sim 239^{\circ}$ の $6.5 \mathrm{mg}$, ピクロロン酸 $10.6 \mathrm{mg}$, 水 $0.3 \mathrm{cc}$ 上り常法により $8 \mathrm{mg}$ 老得た。長杜狀の鮮黃色結晶。分 解點 69 7 $70^{\circ}$ 。分析梿 $\mathrm{N} 16.16 \%, \mathrm{C}_{16} \mathrm{H}_{21} \mathrm{O}_{7} \mathrm{~N}_{5} \mathrm{~S}$ 計算 值 N $16.39 \%$ 。

(7) $\alpha$ ーオキシーケーメチルチオ酪酸 (a) L-メチオニ ンと $\mathrm{HNO}_{2}$ の反鹰 赤染部氏と同核の操作により $\mathrm{Zn}$ 祭 として取出した。 $110^{\circ} \mathrm{O}$ 乾燥物, $[\alpha]_{\mathrm{D}}^{2 \mathrm{D}}=-30.6^{\circ}(\alpha-0$. $25^{\circ}$, c. $0.814 \%$, 水)。(b) (I) $と \mathrm{Ag}_{2} \mathrm{O}$ の反礁 (I) の $0.3 \mathrm{~g}, \mathrm{Ag}_{2} \mathrm{O} 0.73 \mathrm{~g}$, 水 $5 \mathrm{cc}$ を $50^{\circ} \mathrm{C}$ て 3 㭙間撜拌

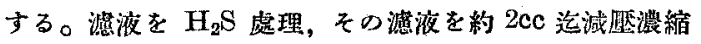


し旋光度を見ると $\alpha=-0.9^{\circ}$ であつた。その液に水を

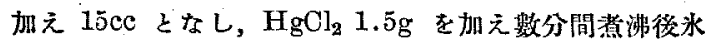
冷する。浾取した結晶を $3 \mathrm{cc}$ の水上り再結晶。この昇

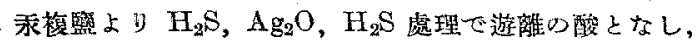

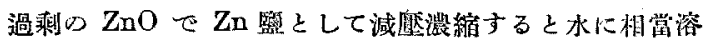
け難い白色の Zn 秏を析出する。0.095g。杜狀結晶。 $110^{\circ} \mathrm{C}$ 今乾燥, $[\boldsymbol{\alpha}]_{\mathrm{D}}^{20}=-5.1^{\circ}\left(\boldsymbol{\alpha}-0.04^{\circ}\right.$, c. $0.784 \%$, 水。分析值 $\mathrm{Zn} 18.76 \%, \mathrm{O}_{10} \mathrm{H}_{16} \mathrm{O}_{6} \mathrm{~S}_{2} \mathrm{Zn}$ 訫算値 $\mathrm{Zn}$ $17.97 \%$ 。

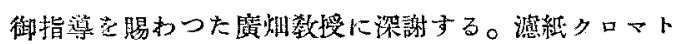
グラフに助力下さつた照时吉男讙阿，分析に協力下さつ

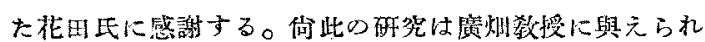

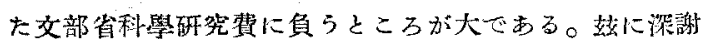
の意を表引る。

\section{一文献 -}

1) E. Fischer et al., Ann., 340, 170 (1905); Ber., 39, 3996 (1906); Ber., 40, 489, 1051 (1907).

2) E. Fischer, H. Scheibler, Ber., 41, 889 (1908); E, Abderhalden, W. Zeisset, Z. physiol. Chem, 200,179 (1931).

3) E. Fischer, R. v. Gravenitz, Ann., 406, 1 (1911); G. Senter, H. D. K. Drew, J. Chem.
Soc., 109, 1091 (I916).

4) A. Neuberger, "Advances in Protein Chemistry," Vol. w, p. 333 (1948).

5) 泉屋信夫, 日化, 71, 500 (1950).

6) H. Gilman, "Organic Chemistry". Vol. I, p. 214 (1945).

7) E. Fischer, L. v, Mechel, Ber., 49, 1355 (1916).

8) W. I. Patterson, H. M. Dyer, V. du Vigneaud, J. Biol. Chem., 116, 277 (1937).

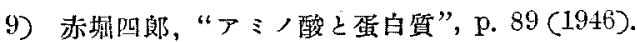

(10) K. Bloch, H. T. Clarke, J. Biol. Chem., 125, 275 (1938).

11) J. S. Fruton, H. T. Clarke, J. Biol. Chem., 106, 667 (1934).

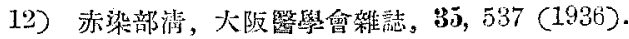

13) E. M. Hill, W. Robson, Biochem. J., 28, 1008 (1934).

14) M. S. Dunn, L. B. Lockland, "Advances" in Protein Chemistry", Vol. ili, p. 353 (1947).

15) 泉屋信大。日化, 70,404 (1949).

16) E, W. Mc Chesney, J. Am. Chem. Soc., 59, 1116 (1937).

\section{天然水中のマンガン含有量について（第 1 2 報）}

田中立治

\section{（第 1 報） 野外に於けるマンガン の迅速定量法 (I)}

從來微量のマンガンを過マンガン酸に酸化してその色 を比色する定量法に打いては過酸化笞，荅鉛酸ナトリの ム, 過硫酸アンモニウム, 過沃素酸カリウム等種々の酸 化柿が用いられていた。前 2 者は酸化放を除くのに滤別 せ补ば坛らず，過硫酸アンモニウムに上る方法は酸化不 充分になることがあり，又能媒と稱して加える銀酤め量 により酸化が圆滑に行われなかったり，比色的に行ら場 合には不當に高い値が得られる゙とともある。落著は過酸
化銀による酸化法りを野外に於ける、ンガンの迅速定量 に㮣用し，满足小べき結果を得た。又微量のマンガンの

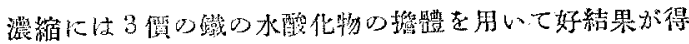

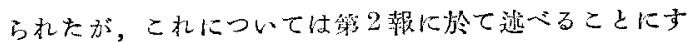
る。

\section{方 法 概 要}

過酸化銀を用いてさ洒のマンガンを過マンガン酸に酸 化する際には試料溶液を $3 N$ 䂭酸酸性にし，之に0.1 $0.2 \mathrm{~g}$ の過酸化銀を湓時に加え, 重湯煎上で 2 時間熱 L

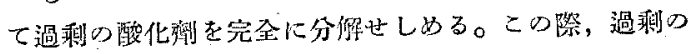

